\title{
Zika virus serological diagnosis: commercial tests and monoclonal antibodies as tools
}

Isaura Beatriz Borges Silva ${ }^{1,2}$, Aldacilene Souza da Silva ${ }^{1}$, Mariana Sequetin Cunha ${ }^{3}$, Aline Diniz Cabral ${ }^{1}$, Kelly Cristina Alves de Oliveira ${ }^{1}$, Elizabeth De Gaspari ${ }^{1,2}$, Carlos Roberto Prudencio ${ }^{1,2 *}$ (1)

${ }^{1}$ Center of Immunology, Adolfo Lutz Institute, São Paulo, SP, Brazil.

${ }^{2}$ Interunits Graduate Program in Biotechnology, University of São Paulo (USP), São Paulo, SP, Brazil.

${ }^{3}$ Division of Vector-Borne Diseases, Adolfo Lutz Institute, São Paulo, SP, Brazil.

\section{Keywords:}

Zika virus

Flaviviruses

Serological diagnosis

Commercial tests

Monoclonal antibody

\begin{abstract}
Zika virus (ZIKV), an emerging arthropod-borne virus (arbovirus) of the Flaviviridae family, is a current issue worldwide, particularly because of the congenital and neurological syndromes associated with infection by this virus. As the initial clinical symptoms of all diseases caused by this group are very similar, clinical diagnosis is difficult. Furthermore, laboratory diagnostic efforts have failed to identify specific and accurate tests for each virus of the Flaviviridae family due to the cross-reactivity of these viruses in serum samples. This situation has resulted in underreporting of the diseases caused by flaviviruses. However, many companies developed commercial diagnostic tests after the recent ZIKV outbreak. Moreover, health regulatory agencies have approved different commercial tests to extend the monitoring of ZIKV infections. Considering that a specific and sensitive diagnostic method for estimating risk and evaluating ZIKV propagation is still needed, this review aims to provide an update of the main commercially approved serological diagnostics test by the US Food and Drug Administration (FDA) and Brazilian National Health Surveillance Agency (ANVISA). Additionally, we present the technologies used for monoclonal antibody production as a tool for the development of diagnostic tests and applications of these antibodies in detecting ZIKV infections worldwide.
\end{abstract}

* Correspondence: carlos.prudencio@ial.sp.gov.br https://doi.org/10.1590/1678-9199-JVATITD-2020-0019 Received: 19 February 2020; Accepted: 6 September 2020; Published online: 18 November 2020 


\section{Background}

Zika virus (ZIKV) is an RNA virus of the Flavivirus genus, Flaviviridae family, that belongs to the arbovirus group, which comprises viruses that share a cycle of transmission via arthropod vectors, most commonly mosquitoes, ticks and flies $[1,2]$. Other viruses that belong to the Flavivirus genus are also some of the most globally relevant viruses in relation to vectorborne diseases, causing worldwide morbidity and mortality, including Dengue virus (DENV) subtypes 1, 2, 3, and 4 and Yellow Fever virus (YFV). ZIKV transmission primarily occurs through the bite of Aedes mosquitoes infected with the virus. One of the most alarming features of ZIKV is that it can be transmitted vertically from mother to fetus during pregnancy or at the time of birth, which differs from other flaviviruses [3]. Moreover, ZIKV exhibits long semen persistence, which is associated with its ability to be transmitted sexually, with great potential for propagation.

Most people infected with ZIKV have no symptoms, and when present, the symptoms are mild, such as headache, skin rash, fever, joint pain, muscle ache, retro-orbital pain and conjunctivitis [4]. It is important to emphasize that these symptoms are non-specific and common to several other infectious diseases, including other arboviruses, such as DENV, YFV, Chikungunya virus (CHIKV), among others. Since infected individuals generally do not present severe illness, they therefore do not seek medical assistance, though death due to ZIKV is rare [5,6]. For this reason, many people may not realize that they have been infected.

ZIKV was isolated for the first time in 1947 in the Ziika forest near Lake Victoria in Uganda [7]. The first documented outbreak of ZIKV outside of the African continent was described in 2007 in Micronesia. However, there were no reports of severe cases described in the literature [8,9]. In late 2013, an increase in the incidence of Guillain-Barré syndrome was observed in French Polynesia after a high number of ZIKV infections were identified during the same period [10].

Subsequently, a small outbreak in the Northeastern Brazil was described in 2015 [11], and in October of the same year, an unusual increase in microcephaly cases in newborns was observed in Brazil, especially in the northeastern region [12]. In response, the country declared a national public health emergency in November $[10,13]$. On February 1, 2016, the World Health Organization (WHO) declared that such complications associated with ZIKV infections constitute a Public Health Emergency of International Concern [14].

ZIKV can be grouped into two main strains: African and Asian. Phylogenetic analysis indicate that ZIKV originated in Africa and then spread to Asia, the Pacific islands and throughout the Americas. The introduction of ZIKV in the Americas was probably due to a single introduction of an Asian strain between May and December 2013, more than 12 months before the detection of ZIKV in Brazil [15]. Some studies have already demonstrated intrinsic differences in pathogenicity/virulence between the African and Asian lineages. The Asian strain has a lower infection rate, lower viral production and low cell death induction that may contribute, at least in part, to the ability to cause persistent infections in the central nervous system of fetuses $[16,17]$.

The structure of ZIKV is very similar to that of other flaviviruses. The structural proteins include the envelope protein (E), capsid protein (C), membrane precursor (prM) and membrane protein (M). ZIKV protein $\mathrm{E}$ is the main viral protein involved in cell receptor binding and entry and, therefore, is considered to be one of the major determinants of ZIKV pathogenesis [18]. Each monomer of protein E contains three ectodomains: domains I, II and III (DI, DII and DIII). These domains are involved in such functions as cell receptor virus binding and fusogenic properties and play a critical role in neutralizing antibody stimulation [19].

The nonstructural protein 1 (NS1) protein is also considered an important antigenic marker of ZIKV and other flaviviruses. NS1 is a glycoprotein that exists as a membrane-associated dimer after translocation to the lumen of the endoplasmic reticulum of virus-infected cells. As the genetic material and viral replication complex are also located in the endoplasmic reticulum, this host cell organelle is essential for flavivirus RNA replication [20]. In addition, infected cells secrete NS1 as a hexameric lipoprotein that interacts with complement system proteins and has many immune system modulation functions that contribute to evasion [20].

The incidence of ZIKV in the Americas peaked in 2016 and decreased substantially over the course of 2017 and 2018, with a slight increase in 2019 [21]. ZIKV transmission has been identified in all North and South American countries, except for Canada. It is noteworthy that in Brazil, 17,041 suspected cases of growth and developmental changes in fetuses that were possibly related to ZIKV infections and other infectious etiologies were reported between 2015 and 2018, with 2865 confirmed cases [22]. Since 2015 until epidemiological week 53 of 2019, the number of cumulative cases across the Americas was 857,648 [23]. In Brazil, 10,768 probable cases were reported throughout 2019 [24].

Epidemiological data contribute to assessing the incidence of infections and their context and complexity, assisting in the setting of goals and selection of necessary interventions [25]. Nonetheless, obtaining reliable epidemiological data is directly related to the efficiency of adequate diagnosis of infections. Concerning flavivirus infections, there is a limitation due to its co-circulation in certain areas, high similarity in clinical symptoms and cross-reactivity in laboratory diagnostic methods. Studies using the Notification Disease Information System (SINAN) database during the period from 2015 to 2017 showed that an increase in individuals reported having ZIKV infections may have contributed to a rise in misreported DENV cases, indicating a scenario in which people infected with Zika were erroneously classified as having DENV infection and vice versa [26].

Overall, inadequate diagnosis can interfere with the risk estimation, propagation, and determination of the true impact 
of ZIKV infection on other arboviruses and, consequently, on an efficient response from public health agencies. Accordingly, this review aims to provide an update of the main commercial serological diagnostic test approved by the US Food and Drug Administration (FDA) and Brazilian National Health Surveillance Agency (ANVISA). This review also aims to present the advantages of monoclonal antibodies as tools for diagnosis, their recent applications in the detection of ZIKV infections and other perspectives regarding ZIKV diagnosis.

\section{Zika Virus Diagnostics}

The most appropriate diagnostic test for the detection of viral infections is dependent on the stage of the disease, which is divided into acute and convalescent phases. The acute phase is characterized by the early stages of infection when viruses replicate in infected cells and the host develops viremia. After the onset of clinical manifestations, there is an initial response to the infection by the production of IgM antibodies against the virus; this immune response is also considered part of the acute phase. The convalescent phase occurs in the late stages of infection, and a more specific and persistent IgG antibody response against the virus develops $[27,28]$. The ideal diagnostic test should have high sensitivity and specificity, which is the ability of the test to correctly identify an individual with the disease and the ability to correctly classify an individual without the disease, respectively. These terms are also defined by the equations: sensitivity $=$ true positives/(true positives + false negatives) and specificity $=$ true negatives/(true negatives + false positives). However, in general, these measures are inversely proportional, meaning that the higher the sensitivity, the lower the specificity, and vice versa [29]. Diagnostic tests can consist of molecular or serological assays. The former are direct assays used for detection and/or quantification of genetic variants, i.e., they are based on the presence of viral nucleic acids in bodily fluids [30]. In contrast, serological assays can be employed to indirectly identify the previous circulating virus and to measure the patient's immune response against the virus by detecting antibodies against the virus in serum. Demonstration of the causative organism or a specific antibody is required for diagnosis of any infection [31]. ZIKV RNA may be detectable in serum for approximately 4-7 days following the onset of symptoms. However, it has been demonstrated that ZIKV RNA remains detectable in serum for approximately 54 days after symptom onset, in urine for 39 days, and in semen for 120 days [32]. Indeed, semen appears to be the fluid in which the virus persists the longest. Nicastri et al. [33] and Barzon et al. [34] reported the detection of viral RNA in semen 188 and 370 days after symptom onset, respectively.

Although IgM levels vary, they are generally positive from the fourth day after the onset of symptoms until up to 12 weeks, and the levels may persist for even longer. The IgG response develops shortly after the IgM response, and it has been shown that IgG levels remain high for at least 2 years after infection [35]. When patients have symptoms and visit clinics, viremia is often already low or undetectable, imposing a narrow diagnostic window for the detection of viral components [36]. Thus, serological diagnosis via antibody detection is an efficient approach to determining infection status over long periods. Serological assays are able to detect ZIKV infection in cases in which virus nucleic acids are no longer detectable. This is partly due to the period in which patients seek medical attention after the onset of symptoms or return from traveling to a ZIKV-affected country [37]. Despite evidence of prolonged persistence of ZIKV nucleic acids in body fluids [38], this genetic material is generally not consistently detectable in serum and urine for prolonged periods.

Zika virus shares approximately $55.6 \%$ amino acid sequence identity with DENV, $46.0 \%$ with YFV, $56.1 \%$ with Japanese Encephalitis virus (JEV) and 57.0\% with West Nile virus (WNV) [39]. This large similarity between flaviviruses often display antibody cross-reactivity, as they share multiple conserved epitopes that can act as a key target for cross-reactive human antibody responses [40]. Considering the co-circulation of flaviviruses in certain geographic areas, the pre-existence of antibodies against some flaviviruses represents a great challenge for understanding the immune response to and pathogenesis of the viruses. Thus, detection tests for IgG against ZIKV are not reliable due to the potential cross-reactivity in those with previous infections by other flaviviruses [37], hindering the ability to fully assess a patient's serological profile. Studies made using Tick-Borne Encephalitis (TBE) and/or YFV vaccinated individuals' samples evaluated the effect on the patterns of antibody responses in primary ZIKV infections. The results showed that pre-existing cross-reactive immunities had a strong influence on the antibody responses in primary ZIKV infections, resulting in higher titers of broadly flavivirus cross-reactive antibodies and alteration in ZIKV-specific antibodies levels [41].

Although ZIKV and DENV show approximately $41 \%$ to $46 \%$ differences in envelope protein amino acid sequence [42], the similarities are sufficient to allow cross-reaction between ZIKV and DENV, and a number of reports demonstrate the difficulty in distinguishing DENV and ZIKV infections serologically [43-46]. Furthermore, the cross-reactivity of flavivirus antibodies associated with co-circulation represents a great challenge in obtaining specific and sensitive diagnostic tests for each virus of the Flaviviridae family. In addition, similar clinical manifestations, and even the presence of many asymptomatic patients, make it even more difficult to accurately diagnose ZIKV.

Public health surveillance monitors infectious diseases in the population. Thus, diagnostic tests has a strong role in providing accurate results that allow pathogen occurrence identification so that measures can be executed to control and prevent them from reappearing. Particularly, serological test is a way to better understand the expansion of the infection through the population, allowing a serosurveillance on a herd level. Tests should be easy to use and provide a rapid result to have a positive impact on care [47]. The dynamics of testing infectious diseases needs to act as a bridge between the laboratory and public health organs to support surveillance activities. Surveillance 
case data applied to perform epidemiological mapping, using geographical information system (GIS) approach, can be helpful for a preventive and control strategies [48].

\section{Approved and Commercial Serologic Tests for Zika Virus}

Given the necessity of establishing strategies for the control and dispersion of ZIKV, the Centre for Disease Control and Prevention (CDC) has established recommended guidelines for ZIKV diagnosis. The diagnostic tools consist of reverse transcriptase reaction assays followed by real-time polymerase chain reaction (RT-qPCR), ZIKV IgM antibody capture immunoenzyme assays (MAC-ELISAs) and plate reduction neutralization tests (PRNTs) $[8,49]$.

The RT-PCR assay is only applicable during the acute phase of infection, when viral RNA is still detectable in body fluids, and the persistence of viral RNA varies according to the biological material examined. The sensitivity of the RT-PCR assay is very important to avoid false negative results [50]. Up to ten mismatches have already been identified between the nucleotide sequences reported in published assays and the consensus sequence of the Asian ZIKV strain, in addition to mismatches in primers and probes used in the RT-PCR amplification. Such inconsistencies are a potential limiting factor for the sensitivity of the test due to the existing genetic variability in the Asian strain $[50,51]$. Therefore, there must be a continuous surveillance to detect new ZIKV variants and an update in molecular methods by modifying the primer and probe sequences to overcome the impact of the mismatches mutations and improve the detection sensitivity.

MAC-ELISA is a serologic test used for qualitative detection of IgM antibodies in the serum or cerebrospinal fluid. Nonetheless, the results can be difficult to interpret due to the possible nonspecific reactivity of antibodies. Consequently, tests determined to be positive, equivocal or inconclusive should be confirmed by PRNT, a serological test based on the ability of specific antibodies present in the serum of patients to neutralize viruses by preventing plaque formation in a cell monolayer. PRNT is currently considered the "gold standard" for differential flavivirus serodiagnosis due to its high specificity. However, this assay has a high cost, requires highly specialized laboratories with adequate equipment to maintain cell culture, and special regulations for working with the active virus; it is also difficult to perform, and 5 to 10 days are required to obtain results [49,52].

Among the available serological commercial tests, the tests developed by Euroimmun AG (Germany) and InBios (USA) are noteworthy. The Euroimmun assay was the first commercially available serological test for ZIKV detection, and it has been extensively evaluated in the literature [53-56]. The anti-Zika virus IgM/IgG/IgA ELISA is based on an ELISA using the Zika virus NS1 protein for the detection of IgM, IgG and IgA in serum samples. Studies such as those by Huzly et al. [53] reported high specificity of this test using different serum samples from patients with previous flavivirus infections. Additionally, L'Huillier et al. [54] conducted a comparative study between Euroimmun IgM and IgG ELISAs and MAC-ELISA and subsequent PRNT for the confirmation of positive or inconclusive results. It was demonstrated that Euroimmun's combined IgG/IgM test presented good specificity (95\%) that was even better than that of MAC-ELISA, though the sensitivity of this test was significantly lower than that of MAC-ELISA (39.5\%).

The InBios assay, also known as the ZIKV Detect 2.0 The IgM Capture ELISA kit, is an assay based on capture ELISA for qualitative detection of IgM antibodies against ZIKV using the viral envelope protein as an antigen. This assay was the first commercial serological test to receive FDA marketing authorization in the USA, granted in May 2019 [57]. Granger et al. [58] and Safronetz et al. [59] demonstrated that the InBios test provides diagnostic results comparable to those of the CDC MAC-ELISA and still exhibited high sensitivity (100\%). The low sensitivity observed with the Euroimmun assay may be due to the high specificity of ZIKV antibodies. Specificity is a critical factor for a diagnostic test, as sensitivity is an important feature in determining its usefulness, and low sensitivity can lead to false negative results. Although additional studies with a larger panel of samples are still needed, these tests have great potential for the serological evaluation of ZIKV infections with reduced time for confirmation of infection, and these tests may decrease the need for PRNT confirmation tests.

The ADVIA Centaur Zika test was the second Zika diagnostic test that the FDA has allowed to be marketed in the USA for detecting ZIKV IgM antibodies. The third and last authorized test to be marketed was LIAISON XL Zika Capture IgM Assay II. Previously, these tests had only been authorized for emergency use under the FDA's Emergency Use Authorization (EUA) authority. A unique serological test that is still under the FDA's EUA is DPP Zika IgM Assay System from Chembio Diagnostic Systems [60]. In Brazil, ANVISA has also approved the registration of some of these commercial tests to broaden access to diagnosis and allow for greater monitoring of ZIKV infection. Currently, there are 48 tests approved by ANVISA; 36 are serologic tests, some of which are described in Table 1 [61]. Most of them present elevated sensitivity and specificity. However, these tests are generally not validated using samples from more than two different countries or regions, limiting their use in a wide and universal way due to the different circulating strains of ZIKV. Different ZIKV isolates may present genotypic and phenotypic variations that influence the manner by which the immune system responds and thus the antibody response to the virus [62]. Overall, these assays have good prospects for use in routine diagnostic laboratories if they pass for a systematic clinical evaluation.

\section{Monoclonal Antibodies Used in Zika Virus Diagnosis}

Monoclonal antibodies (MAbs) are products of individual B-cell clones. They have broad applicability in therapies and drug targeting, and have a profound impact on the immunodiagnostics 
Table 1. Main currently approved ANVISA tests.

\begin{tabular}{|c|c|c|c|c|c|}
\hline Test & Company & Test format & $\begin{array}{c}\text { ZIKV } \\
\text { antigen }\end{array}$ & Sensitivity & Specificity \\
\hline $\begin{array}{c}\text { DPP Zika lgM/lgG } \\
\text { Assay System }\end{array}$ & $\begin{array}{c}\text { Chembio Diagnostic } \\
\text { Systems (USA) }\end{array}$ & Immunochromatographic & NS1 & $\begin{array}{l}\lg M: 89.5 \% \\
\operatorname{lgG}: 97.5 \%\end{array}$ & $\begin{array}{l}\lg M: 97.7 \% \\
\operatorname{lgG}: 98.3 \%\end{array}$ \\
\hline $\begin{array}{c}\text { RecombiLISA Zika } \\
\text { IgM ELISA Kit }\end{array}$ & CTK Biotech (USA) & ELISA & NS1 & $94.7 \%$ & $98.5 \%$ \\
\hline ZIKV IgM ELISA kit & $\begin{array}{l}\text { DIA.PRO Diagnostic } \\
\text { Bioprobes Srl (Italy) }\end{array}$ & ELISA & - & $\begin{array}{l}\lg M: 69 \% \\
\operatorname{lgG}: 80.5\end{array}$ & $\begin{array}{l}\text { IgM: } 96 \% \\
\text { IgM: } 94 \%\end{array}$ \\
\hline $\begin{array}{l}\text { LIAISON XL Zika } \\
\text { Capture IgM Assay }\end{array}$ & $\begin{array}{l}\text { DiaSorin } \\
\text { (Italy) }\end{array}$ & $\begin{array}{c}\text { Microparticle } \\
\text { antibody capture } \\
\text { chemiluminescence } \\
\text { immunoassay }\end{array}$ & NS1 & $100 \%$ & $91.2 \%$ \\
\hline Zika ELISA IgM/ IgG & $\begin{array}{l}\text { Vircell S. L. } \\
\text { (Spain) }\end{array}$ & ELISA & - & $\lg M$ and $\operatorname{lgG}: 91 \%$ & IgM and IgG: $99 \%$ \\
\hline $\begin{array}{c}\text { ZIKV-DENV-CHIKV } \\
\lg M / \lg G \text { IFA }\end{array}$ & & Immunofluorescence & Infected cells & $\begin{array}{l}\lg M: 93.3 \% \\
\lg G: 94.7\end{array}$ & $\begin{array}{l}\lg M: 94.4 \% \\
\operatorname{lgG}: 94 \%\end{array}$ \\
\hline $\begin{array}{l}\text { Anti-Zika virus } \\
\text { ELISA lgM/lgG }\end{array}$ & $\begin{array}{l}\text { Euroimmun } \\
\text { (Germany) }\end{array}$ & ELISA & NS1 & $\begin{array}{l}\lg M: 87 \% \\
\lg \mathrm{g}: 100 \%\end{array}$ & IgM and lgG: $97 \%$ \\
\hline $\begin{array}{l}\text { IIFT Arboviral Fever } \\
\text { Mosaic } 2 \text { lgM/lgG }\end{array}$ & & Immunofluorescence & Infected cells & $\begin{array}{l}\lg M: 96.9 \% \\
\text { IgG: } 96.8 \%\end{array}$ & $\begin{array}{l}\lg M: 98.1 \% \\
\text { IgG: } 93.4 \%\end{array}$ \\
\hline $\begin{array}{l}\text { NovaLisa Zika Virus } \\
\lg M \mu \text {-capture }\end{array}$ & $\begin{array}{c}\text { NovaTec } \\
\text { Immunodiagnostica GmbH } \\
\text { (Germany) }\end{array}$ & ELISA & NS1 & $98.5 \%$ & $100 \%$ \\
\hline Elecsys $®$ Zika lgG & $\begin{array}{c}\text { Roche Diagnostics } \\
\text { (Switzerland) }\end{array}$ & ELISA & - & $93.11 \%$ & $99.82 \%$ \\
\hline $\begin{array}{c}\text { STANDARD E } \\
\text { Zika IgM }\end{array}$ & $\begin{array}{l}\text { SD Biosensor Inc. } \\
\text { (South Korea) }\end{array}$ & ELISA & - & $100 \%$ & - \\
\hline $\begin{array}{l}\text { STANDARD Q } \\
\text { Zika IgM/lgG }\end{array}$ & & Immunochromatography & - & $\begin{array}{l}\lg M: 98 \% \\
\lg \mathrm{G}: 75.9 \%\end{array}$ & $\begin{array}{l}\text { IgM: } 100 \% \\
\text { IgG: } 70 \%\end{array}$ \\
\hline Zika IgG/lgM & $\begin{array}{c}\text { Ebram Laboratory } \\
\text { Products (Brazil) }\end{array}$ & Immunochromatography & - & $99.9 \%$ & $98.9 \%$ \\
\hline $\begin{array}{c}\text { Imuno-Rapid Zika } \\
\text { IgG/lgM }\end{array}$ & $\begin{array}{c}\text { Wama Laboratory } \\
\text { Products (Brazil) }\end{array}$ & Immunochromatography & $\begin{array}{c}\text { ZIKV } \\
\text { inactivated }\end{array}$ & $96.2 \%$ & $\begin{array}{l}\operatorname{lgG}: 99.1 \% \\
\text { IgM: } 98.2 \%\end{array}$ \\
\hline Allserum Zika IgM & $\begin{array}{l}\text { Mbiolog Diagnostic } \\
\text { (Brazil) }\end{array}$ & ELISA & NS1 & $100 \%$ & $94.4 \%$ \\
\hline $\begin{array}{l}\text { Kit Xgen Zika Virus } \\
\text { lgG/lgM }\end{array}$ & $\begin{array}{l}\text { Mobius Life Science } \\
\text { Industry and Commerce } \\
\text { of Laboratory Products } \\
\text { (Brazil) }\end{array}$ & ELISA & NS1 & $\begin{array}{l}\operatorname{lgG}: 100 \% \\
\lg M: 98 \%\end{array}$ & $\begin{array}{l}\operatorname{lgG}: 98 \% \\
\text { IgM: } 98 \%\end{array}$ \\
\hline OL Zika Ag NS1 & $\begin{array}{l}\text { Orangelife Commerce and } \\
\text { Industry (Brazil) }\end{array}$ & Immunochromatography & - & $90.2 \%$ & $99.5 \%$ \\
\hline OL Zika IgM/lgG & & Immunochromatography & - & $\begin{array}{l}\lg M: 93 \% \\
\operatorname{lgG}: 94 \%\end{array}$ & $\begin{array}{l}\text { IgM: } 97 \% \\
\text { IgG: } 98 \%\end{array}$ \\
\hline Zika IgG/lgM Rapid Test & $\begin{array}{l}\text { Diagnostic Industry and } \\
\text { Commerce (Brazil) }\end{array}$ & Immunochromatography & - & - & - \\
\hline ECO F Zika lgG/lgM & $\begin{array}{l}\text { Eco Diagnostic Ltda } \\
\text { (Brazil) }\end{array}$ & Immunofluorescence & - & $98 \%$ & $99 \%$ \\
\hline ECO F Zika Ag & & Immunofluorescence & NS1 & $97 \%$ & $97 \%$ \\
\hline ZiKa lgG/lgM ECO Teste & & Immunochromatography & - & $97.38 \%$ & $\begin{array}{c}\lg M: 100 \% \text { e } \operatorname{lgG}: \\
96.34 \%\end{array}$ \\
\hline
\end{tabular}

NS1: Nonstructural protein 1. 
of infections. MAbs interact with a single antigenic determinant, allowing for specific reactivity and accurate identification of the organism of interest. This feature confers a great advantage to MAbs versus polyclonal antibodies, which have different epitope specificities and affinities $[63,64]$. Moreover, MAbs are relatively easy to use and introduce into trials.

Regarding MAb production, advances in molecular biology and genetic engineering over the years have led to different methods of producing and modifying these antibodies, as opposed to the traditional technique of hybridoma production. Some of these MAbs are produced through cell-free libraries, combinatorial synthetic libraries, affinity maturation, and production in transgenic animals and plants, as well as several other technologies, allowing for great robustness and interaction efficiency with a specific target [64].

The development of MAbs has been mainly focused on the development of therapies for cancer, autoimmune diseases, and inflammatory conditions. However, the application of MAbs for infectious diseases still has limitations [65]. One of the main reasons for this scenario is the economic viability for $\mathrm{MAb}$ production against targets that may cause an episodic disease, hindering their continued production. MAb production generally involves stages of establishment and optimization of cell culture process, following antibody production, purification, and polishing steps. The costs of the final product can still be a limiting factor for commercial manufacturing. Meanwhile, alternatives have been made to maximize product yield and to improve the robustness [66], in order to enable MAbs application expansion in the field of infectious diseases.
Figure 1 illustrates an antibody-capture assay, representing how monoclonal antibodies can be used for a serology assay to detect IgM or IgG antibodies in patient's serum samples. The capturing method typically employs a capture antibody, anti-IgG or anti-IgM, coated in a surface, then serum sample is incubated, followed by addition of ZIKV antigen and a specific anti-ZIKV MAb conjugated with an enzyme. A substrate for the enzyme is then added and, after a short incubation, the signal is measured.

Despite the worldwide effort to facilitate flavivirus diagnostics, no fully validated serological test shows good sensitivity and specificity without the interference of false positive or negative results and is also robust and rapid. Accordingly, the search for MAbs that specifically recognize each virus of this family is extremely relevant and has been addressed by many researchers. Table 2 presents the main monoclonal antibodies against ZIKV currently reported in the literature. To date, there are 21 MAbs that mainly target ZIKV E protein, with DIII being the predominant epitope. All these MAbs demonstrate neutralizing activity or specific detection. Table 3 lists selected studies in which some of these MAbs have been applied in diagnostic tests for ZIKV.

Among the tests referred in Table 3, the rapid test developed by Kim et al. [77] was the first rapid test to be developed and the first test to receive approval from ANVISA with cooperation of BahiaFarma (Bahia, Brazil) and GenBody Inc. (Cheonan, Korea). Regarding MAb obtention techniques, hybridoma production is the most well established, is considered the most traditional methodology and is still the most widely used. This technique

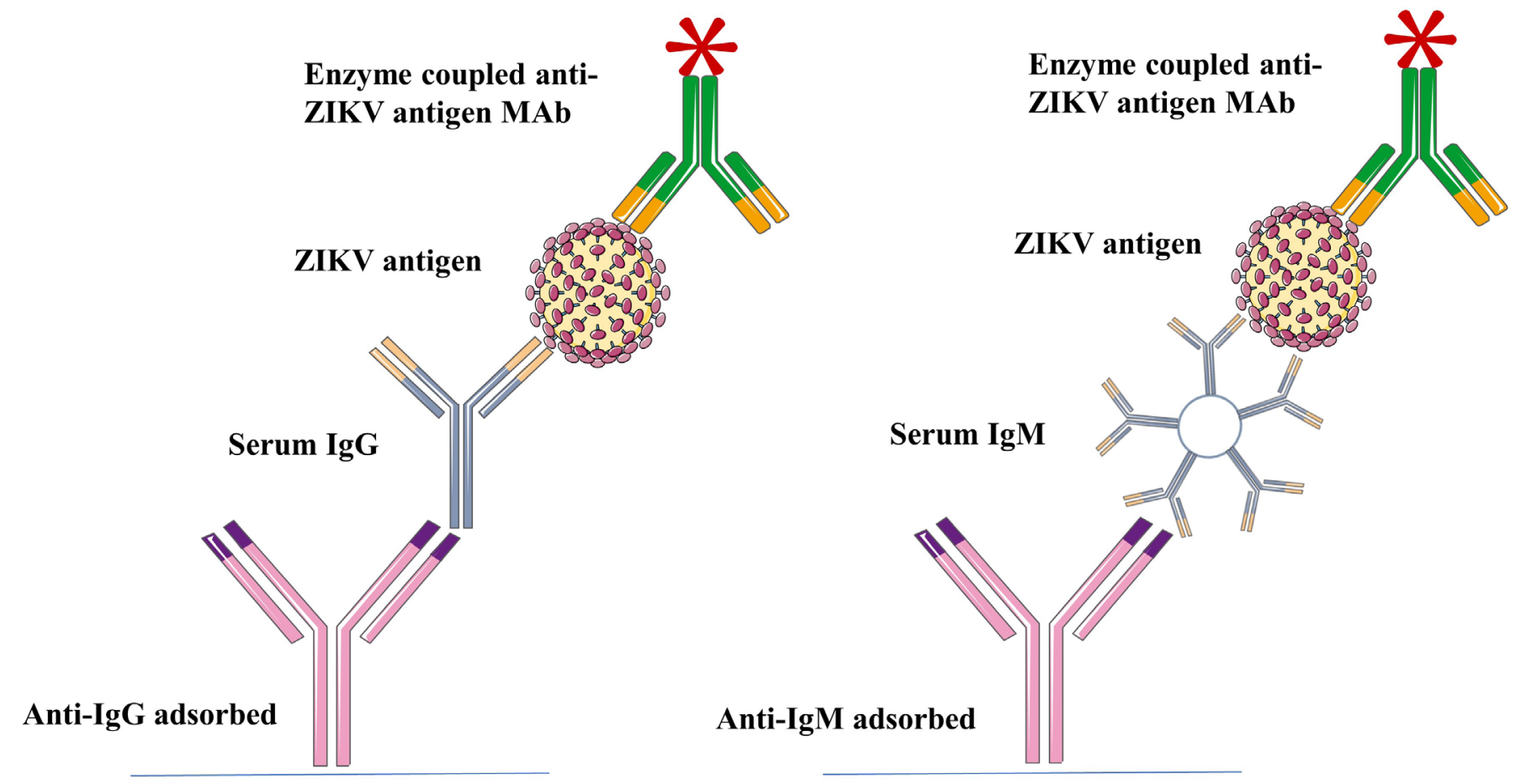

Figure 1. Schematic representation of an antibody capturing serology method for detection of IgG and IgM antibodies in serum sample using a monoclonal antibody that recognizes ZIKV antigen. 
is based on the fusion of B lymphocytes with myeloma cells to generate hybrid cells that continuously produce antibodies in vitro [82]. However, the steps for producing hybrid cells are laborious and dependent on immune response induction. Alternatively, techniques involving isolation of infected plasmoblasts or memory B cells from infected individuals have been widely employed. The great advantage of these methodologies is the isolation of antibodies from donors who carry antibodies derived from cells that were activated naturally, allowing for full exploration of the strength of the human antibody response to a pathogen [83].

The MAb developed by Balmaseda et al. [74] is derived from a panel of MAbs produced by immortalization of memory B cells using Epstein-Barr virus from four infected ZIKV donors of the

Table 2. Main monoclonal antibodies against ZIKV.

\begin{tabular}{|c|c|c|}
\hline Source & MAb & Epitopes \\
\hline Murine & 1 (2A10G6) [67] & Fusion Loop \\
\hline Human & 1 (ZKA64) [68] & DIII \\
\hline Murine & 2 (ZK54/ZV67) [69] & DIII/DIII \\
\hline Human & 3 (Z3L1/Z23/Z20) [70] & $\begin{array}{c}\text { DI, DII/ } \\
\text { DIII, DI/DIII }\end{array}$ \\
\hline Human & 1 (ZIKV-117) [71] & DIl \\
\hline Murine & $1(\mathrm{ZV}-2)[72]$ & $\mathrm{E}$ \\
\hline Human & $1(Z 004)[73]$ & DIII \\
\hline Human & 1 (ZKA35) [74] & NS1 \\
\hline Human & $2(\mathrm{~m} 301 / \mathrm{m} 302)[75]$ & DIII \\
\hline Murine & 1 (1F12) [76] & NS1 \\
\hline Murine & $2(J 5 E 1 / J 2 G 7)[77]$ & E/NS1 \\
\hline Human & 1 (ZK2B10) [78] & DIII \\
\hline Human & 3 (P1F12/P1H09/P1804) [79] & $\mathrm{E}$ \\
\hline Human & 1 (ZIKV-195) [80] & $\mathrm{DI} / \mathrm{DIl}$ \\
\hline
\end{tabular}

MAb: monoclonal antibody; E: envelope protein; DI: envelope domain I; DII: envelope domain II; DIII: envelope domain III; NS1: nonstructural protein 1. recent epidemic. Robbiani et al. [73] and Sapparapu et al. [71] also isolated MAbs by expanding memory B cell clones from ZIKV-infected individuals. Prior characterization of these clones was performed based on their ability to bind viral proteins, such as NS1 and E, and their ability to neutralize ZIKV infection.

In addition to the methodologies for MAb obtention, phage display has emerged as one of the main alternatives for the generation of human recombinant MAbs. Phage display enables to select human MAbs without in vivo immunization through the selection of combinatorial libraries of human antibodies displayed on filamentous phage surfaces against a target antigen, allowing for rapid and economical MAbs generation [84]. The phage display biopanning process mimics $\mathrm{B}$ cell clonal selection of the immune system by enriching phage particles that express antibodies with a desired specificity [85]. Therefore, the technique is highly robust due to the high stability of the phages, allows for the control of biochemical parameters throughout the selection process, and can shape the specificity profile of an antibody from the beginning. Wu et al. [75] identified a panel of human MAbs with high affinity and specificity for ZIKV DIII from a phage display naïve antibody library.

Phage display is also considered an important tool for mapping the epitopes of monoclonal antibodies. In this regard, Ravichandran et al. [85] explored different approaches using whole-genome fragment phage display libraries covering the entire ZIKV genome. From this library, the authors mapped some ZIKV-specific MAbs, selected ZIKV-E-specific antibodies from the serum and urine of infected patients and performed comprehensive antibody repertoire analyses of these samples, allowing for the assessment of the immune response against viral infections and the identification of targets for serodiagnosis.

The abovementioned techniques include different antibody formats, such as whole antibodies, fragment antigen binding (Fab) or single-chain variable fragments ( $\mathrm{scFv}$ ). Each of these formats has advantages and disadvantages based on the desired application. For diagnostic methods, such as immunohistochemistry, the lack of Fc ensures the reduction

Table 3. Monoclonal antibodies used in ZIKV diagnostic tests.

\begin{tabular}{|c|c|c|c|c|c|}
\hline MAb & $\begin{array}{c}\text { Molecule(s) } \\
\text { detected }\end{array}$ & Test format & $\begin{array}{c}\text { Method of MAb } \\
\text { isolation }\end{array}$ & Sensitivity & Specificity \\
\hline ZV-2 [72] & E protein & Electrochemiluminescence & Hybridoma & $\begin{array}{c}1 \mathrm{PFU} \text { in } 100 \mu \mathrm{l} \text { of } \\
\text { samples }\end{array}$ & - \\
\hline Anti-ZIKV NS1 [81] & NS1 protein & Immunochromatography & Hybridoma & $81 \%$ & $86 \%$ \\
\hline ZKA35 [74] & NS1 protein & Blockade-of-binding ELISA & $\begin{array}{l}\text { Memory B cells from } \\
\text { infected individuals }\end{array}$ & $95 \%$ & $91.9 \%$ \\
\hline J5E1 and J2G7 [77] & $\lg G$ and $\lg M$ & Immunochromatography & Hybridoma & $\begin{array}{l}99 \% \lg G \\
96.7 \% \lg M\end{array}$ & $\begin{array}{l}99.3 \% \lg G \\
98.7 \% \lg M\end{array}$ \\
\hline $\begin{array}{l}\text { P1F12, P1H09 and } \\
\text { P1804 [79] }\end{array}$ & Zika particles & ELISA & $\begin{array}{l}\text { Plasmablast from } \\
\text { infected individuals }\end{array}$ & - & - \\
\hline
\end{tabular}

MAb: monoclonal antibody; E: envelope protein; NS1: nonstructural protein 1; PFU: plaque-forming unit. 
of non-specific binding in addition to a good tissue distribution [86]. Given this advantage, single-domain antibodies (sdAbs) have emerged with great potential for diagnostic applications, mainly due to their high stability and ability to recognize cavities and cracks in the surface of proteins that cannot be recognized by conventional recombinant antibody formats. In addition, these antibodies have a low cost and are relatively easy to produce compared with other antibody formats [87]. Considering the need to develop rapid and effective diagnostic methods and the increasing use of antibody-based health products, sdAbs can be considered an important biotechnological tool for application in the diagnosis of infections with the ability to cause sudden outbreaks, as in ZIKV infection.

\section{Other Perspectives in the Development of Serological Diagnoses for Zika Virus}

Other innovative methodologies have been applied for the development of serological diagnostics with the potential to outperform conventional methodologies in terms of speed and sensitivity. The reporter virus neutralization test (RVNT) represents a very promising alternative to the PRNT. RVNT uses luciferase-labelled ZIKV and DENV, and neutralizing antibodies can be quantified within $24 \mathrm{~h}$ instead of the typical 7-day period required for plaques to be visible with the PRNT method [57]. Wang et al. [88] developed a capacitive biosensor using microwires coated with the ZIKV envelope protein for the detection of serum antibodies; this biosensor represents a robust label-free assay that enables rapid diagnosis of infection at the point of care (POC). Mishra et al. [89] used a designed platform of peptide array to identify discriminant epitopes for serodiagnosis of ZIKV infection. Based on results obtained with peptide array, they developed a ZIK NS2B peptide ELISA that presented high sensitivity (96\%) and specificity and (95.9\%).

In addition, Kareinen et al. [90] developed a time-resolved Förster resonance energy transfer (TR-FRET) assay involving two chromophore-labelled proteins (ZIKV NS1 protein and a superantigen) that bind simultaneously to an antibody present in a patient's serum. This technique showed high sensitivity and specificity, with the potential to be applied in POC diagnoses. Zhang et al. [91] also constructed a highly multiplexed and programmable peptide array platform containing the ZIKV NS1 and DENV2 antigens on a nanostructured plasmonic gold (pGOLD) platform. The chip can capture IgG and IgA antibodies against ZIKV and DENV antigens in patient serum. The pGOLD platform is capable of amplifying near-infrared fluorescence by up to $\sim 100$ times, allowing for the sensitive analysis of multiple analytes.

\section{Final Considerations}

ZIKV infections constitute a major public health problem in Brazil and around the world, mainly due to the magnitude of its complications, and there are still major challenges in our understanding of ZIKV infection mechanisms. Among them, the lack of complete understanding regarding the risk of complications according to different strains of the ZIKV, possible environmental, genetic or other cofactors that may increase the risk of complications and the lack of knowledge of the role of asymptomatic infections and other modes of transmission play in the general dynamics of circulation. This scenario makes it difficult to fully characterize the damage that ZIKV infections can cause.

Despite the great advances in serological assays in the last years, the incomplete knowledge about the pre-existing immunity for other flavivirus of the population in endemic countries, may impose difficulties in diagnosis [92]. Some improvements allowing multiplexing of detection assays to numerous arbovirus, providing a serological panel of an individual and high throughput testing, would increase the quality of serologic data generated. Moreover, the implementation of tests that present portable, rechargeable devices and the possibility to be conducted without extensive technical skills in the communities reality, may also facilitate determination of infection spread and the level of care [93].

Since the beginning of the ZIKV epidemic, many efforts from health care organizations around the world have been applied to the development of plans for ZIKV control. In 2016, the WHO implemented the Zika Strategic Response Plan, which involves four main objectives to support governments in preventing and managing the complications caused by this virus and mitigating the socioeconomic consequences, including detection, prevention, care and support, and research [94]. In Brazil, different strategies were developed by the Ministry of Health, including developing a National Microcephaly Coping Plan through the mobilization and control of Aedes aegytpi, updating surveillance protocols and responding to ZIKV infections and its resulting complications. Moreover, for the first time, the Ministry of Health has organized a network of integration between managers, researchers and civil society to cope with the disease: Renezika. The creation of this network has demonstrated the ability of the Brazilian scientific community to respond to major international health problems and to propose relevant activities such that future emergencies can be prevented with rapid and effective action.

\section{Conclusion}

Despite the limitations in flavivirus serological assays due to high cross-reactivity, many advancements have been made in ZIKV diagnosis, even with the decrease in the number of infected patients. Investment in the development of innovative methodologies to obtain immunobiological products quickly and effectively represents a crucial factor for the advancement of public health systems worldwide. Contemporary molecular biology and molecular immunology technologies, such as antibody engineering and phage display, allow for the possibility of producing a specific human antibody with relatively high affinity to a target molecule in vitro without in vivo immunization. The 
application of these biomolecules in innovative technologies, such as biosensor chips, with potential application in POC diagnosis may enable increased epidemiological control efficiency. These tests may ensure accurate evaluation of ZIKV infection rates, contributing to the development of efficient public policies to combat this infection.

\section{Abbreviations}

ANVISA: National Health Surveillance Agency; C: capsid protein; CDC: Centre for Disease Control and Prevention; CHIKV: Chikungunya virus; DENV: Dengue virus; DI: envelope domain I; DII: envelope domain II; DIII: envelope domain III; E: envelope protein; Fab: fragment antigen binding; FDA: Food and Drug Administration; GIS: geographical information system; JEV: Japanese encephalitis virus; M: membrane protein; Mabs: monoclonal antibodies; MAC-ELISAs: IgM antibody capture immunoenzyme assays; NS1: nonstructural protein 1; PFU: plaque-forming unit; $\mathrm{pGOLD}$ : nanostructured plasmonic gold; POC: point of care; prM: membrane precursor; PRNTs: plate reduction neutralization tests; RT-qPCR: reverse transcriptase reaction assays followed by real-time polymerase chain reaction; RVNT: reporter virus neutralization test; scFv: single-chain variable fragments; sdAbs: single-domain antibodies; SINAN: Notification Disease Information System; TBE: tick-borne encephalitis; WHO: World Health Organization; WNV: West Nile virus; YFV: Yellow Fever virus; ZIKV: Zika virus.

\section{Acknowledgements}

The authors would like to thank the Immunology and Virology Department of Adolfo Lutz Institute and Interunits Graduate Program in Biotechnology from University of São Paulo.

\section{Availability of data and materials}

All data generated or analyzed during this study are included in this article.

\section{Funding}

This study was financed in part by the Coordination of Improvement of Postgraduate Level Personnel (CAPES), Brazil, finance code 1744620; the National Council for Scientific and Technological Development (CNPq)/CAPES under grant CNPq/ CAPES/MS-DECIT n. 440812/2016-0; and FINEP under grant n. 01.16.0075, and coordination by Dr. Carlos Prudencio.

\section{Competing interests}

The authors declare that they have no competing interests.

\section{Authors' contributions}

IBBS, ASS, MSC and KCAO performed the literature search and wrote the paper. ADC, EDG and CRP wrote the paper and participated in the revisions of it. All authors read and approved the final manuscript.

\section{Ethics approval}

Not applicable.

\section{Consent for publication}

Not applicable.

\section{References}

1. Go YY, Udeni BR, Chong-Kyo L. Zoonotic encephalitides caused by arboviruses: transmission and epidemiology of alphaviruses and flaviviruses. Clinl Exp Vaccines Res. 2014 Jan;3(1):58-77. doi: 10.7774/ cevr.2014.3.1.58.

2. Lopes N, Nozawa C, Linhares RE. [General features and epidemiology of emerging arboviruses in Brazil]. Rev Pan-Amaz Saude. 2014 Sep;5(3):5564. doi: 10.5123/S2176-62232014000300007. [Article in Portuguese].

3. Zorrilla CD, García García I, García Fragoso L, De La Veja A. Zika virus infection in pregnancy: maternal, fetal, and neonatal considerations. J Infect Dis. 2017 Dec 16;216(10 Suppl):S891-6. doi: 10.1093/infdis/jix448.

4. Lopes MH, Miyaji KT, Infante V. Zika virus. Rev Assoc Med Bras. 2016 Jan-Feb;62(41):4-9. doi: 10.1590/1806-9282.62.01.4.

5. Centers for Disease Control and Prevention [Internet]. Zika virus symptoms [cited 2019 May 21]. Available from: https://www.cdc.gov/ zika/symptoms/symptoms.html.

6. World Health Organization [Internet]. Zika virus key facts [cited 2018 Jul 20]. Available from: https://www.who.int/news-room/fact-sheets/ detail/zika-virus.

7. Dick GW, Kitchen SF, Haddow A. Zika virus (I): isolation and serological specificity. Trans R Soc Trop Med Hyg. 1952 Sep;46(5):509-20. doi: 10.1016/0035-9203(52)90042-4.

8. Lanciotti RS, Kosoy OL, Laven JJ, Velez JO, Lambert AJ, Johnson AJ, et al. Genetic and serologic properties of Zika virus associated with an epidemic, Yap State, Micronesia, 2007. Emerg Infect Dis. 2008 Aug;14(8):1232-9. doi: 10.3201/eid1408.080287.

9. Duffy MR, Chen TH, Hancock WT, Powers AM, Kool JL, Lanciotti RS, et al. Zika virus outbreak on Yap Island, Federated States of Micronesia. N Engl J Med. 2009 Jun 11;360(24):2536-43. doi: 10.1056/NEJMoa0805715.

10. Oehler $E$, Watrin L, Larre $P$, Leparc-Goffart I, Lastère $S$, Valour $F$, et al. Zika virus infection complicated by Guillain-Barré syndrome: case report, French Polynesia, december 2013. Euro Surveill. 2014 Mar 6;19(9):20720. doi: 10.2807/1560-7917.es2014.19.9.20720.

11. Cunha MS, Esposito DL, Rocco IM, Maeda AY, Vasami FG, Nogueira JS, et al. First complete genome sequence of Zika virus (Flaviviridae, Flavivirus) from an autochthonous transmission in Brazil. Genome Announc. 2016 Mar 3;4(2):e00032-16. doi: 10.1128/genomeA.00032-16.

12. Schuler-Faccini L, Ribeiro EM, Feitosa IM, Horovitz DD, Cavalcanti DP, Pessoa $A$, et al. Possible association between Zika virus infection and microcephaly: Brazil, 2015. MMWR Morb Mortal Wkly Rep. 2016 Jan 29;65(3):59-62. doi: 10.15585/mmwr.mm6503e2.

13. Cao-Lormeau VM, Roche C, Teissier A, Robin E, Berry AL, Mallet HP, et al. Zika virus, French Polynesia, South Pacific, 2013. Emerg infect Dis. 2014 Jun;20(6):1085-6. doi: 10.3201/eid2006.140138.

14. World Health Organization [Internet]. Zika virus and complications: 2016 public health emergency of international concern [cited 2020 Aug 4]. Available from: https://www.who.int/emergencies/zika-virus-tmp/en/.

15. Faria NR, Azevedo RS, Kraemer MU, Souza R, Cunha MS, Hill SC, et al. Zika virus in the Americas: early epidemiological and genetic findings. Science. 2016 Apr 15;352(6283):345-349. doi: 10.1126/science.aaf5036.

16. Saiz JC, Martín-Acebes MA, Bueno-Marí R, Salomón OD, Villamil-jiménez LC, Heukelbachet J, et al. Zika virus: what have we learnt since the start of the recent epidemic? Front Microbiol. 2017 Aug 22;8:1554. doi: 10.3389/ fmicb.2017.01554. 
17. Simonin $Y$, van Riel D, van de Perre P, Rockx B, Salinas S. Differential virulence between Asian and African lineages of Zika virus. PLoS Negl Trop Dis. 2017 Sep 21;11(9):e0005821. doi: 10.1371/journal.pntd.0005821.

18. Heinz FX, Stiasny K. The antigenic structure of Zika virus and its relation to other flaviviruses: implications for infection and immunoprophylaxis. Microbiol Mol Biol Rev. 2017 Feb 8;81(1):e00055-16. doi: 10.1128/ MMBR.00055-16.

19. Shi Y, Gao GF. Structural biology of the Zika virus. Trends Biochem Sci. 2017 Jun;42(6):443-456. doi: 10.1016/j.tibs.2017.02.009.

20. Brown WC, Akey DL, Konwerski JR, Tarrasch JT, Skiniotis G, Kuhn RJ, et al. Extended surface for membrane association in Zika virus NS1 structure. Nat Struct Mol Biol. 2016 Sep;23(9):865-7. doi: 10.1038/nsmb.3268.

21. World Health Organization. Zika epidemiology update: July 2019: global overview. Geneva: World Health Organization; Jul 2019.

22. Ministério da Saúde, Secretaria de Vigilância em Saúde (BR). Monitoramento integrado de alterações no crescimento e desenvolvimento relacionadas à infecção pelo vírus Zika e outras etiologias infecciosas, até a Semana Epidemiológica 52 de 2018. Boletim Epidemiológico. 2019 Apr;50(13):1-18.

23. Health Information Platform for the Americas [Internet]. Zika total cases by the Americas region and subregions cumulative cases [cited 2020 Aug 4]. Availabe from: https://www.paho.org/data/index.php/en/?option=com_ content\&view=article\&id=525:zika-subregions-en\&ltemid=352.

24. Ministério da Saúde, Secretaria de Vigilância em Saúde (BR) Monitoramento dos casos de arboviroses urbanas transmitidas pelo Aedes (dengue, chikungunya e Zika), semanas epidemiológicas 01 a 52. Boletim Epidemiológico. 2020 Jan;51(2):1-16

25. Barata RB. Epidemiologia e políticas públicas. Rev Bras Epidemiol. 2013 Mar;16(1):3-17. doi: 10.1590/S1415-790X2013000100001.

26. Oliveira JF, Rodrigues MS, Skalinski LM, Santos AE, Costa LC, Cardim LL, et al. Interdependence between confirmed and discarded cases of dengue, chikungunya and Zika viruses in Brazil: a multivariate time-series analysis. PLoS One. 2020 Feb 3;15(2):e0228347. doi: 10.1371/journal.pone.0228347.

27. Maeda A, Maeda J. Review of diagnostic plaque reduction neutralization tests for flavivirus infection. Vet J. 2013 Jan;195(1):33-40. doi: 10.1016/j. tvjl.2012.08.019.

28. Charrel RN, Leparc-Goffart I, Pas S, Lamballerie X, Koopmans M, Reuskenc C. Background review for diagnostic test development for Zika virus infection. Bull World Health Organ. 2016 Aug 1;94(8):574-584. doi: 10.2471/BLT.16.171207.

29. Parikh R, Mathai A, Parikh S, Sekhar GC, Thomas R. Understanding and using sensitivity, specificity and predictive values. Indian J Ophthalmol. 2008 Jan-Feb;56(1):45-50. doi: 10.4103/0301-4738.37595.

30. Colombo TE, Terzian AC, Araújo JP Jr, Parreira R, Cabrera EM, Santos IN, et al. Zika detection: comparison of methodologies. Brazilian J Microbiol. 2018 Jan-Mar;49(1):144-147. doi: 10.1016/j.bjm.2017.04.011.

31. Peaper DR, Landry ML. Laboratory diagnosis of viral infection. Handb Clin Neurol. 2014;123:123-47. doi: 10.1016/B978-0-444-53488-0.00005-5.

32. Paz-Bailey G, Rosenberg ES, Doyle K, Munoz-Jordan J, Santiago GA, Klein $\mathrm{L}$, et al. Persistence of Zika virus in body fluids: final report. N Engl J Med. 2017 Feb 14;379(13):1234-43. doi: 10.1056/NEJMoa1613108.

33. Nicastri E, Castilletti C, Liuzzi G, lannetta M, Capobianchi MR, Ippolito $\mathrm{G}$, et al. Persistent detection of Zika virus RNA in semen for six months after symptom onset in a traveller returning from Haiti to Italy, February 2016. Euro Surveill. 2016 Aug 11;21(32):30314. doi: 10.2807/1560-7917. ES.2016.21.32.30314

34. Barzon L, Percivalle E, Pacenti M, Rovida F, Zavattoni M, del Bravo P, et al. Virus and antibody dynamics in travelers with acute Zika virus infection. Clin Infect Dis. 2018 Apr 3;66(8):1173-80. doi: 10.1093/cid/cix967.

35. Zhao LZ, Hong WX, Wang J, Yu L, Hu FY, Qiu S, et al. Kinetics of antigenspecific $\operatorname{lgM} / \operatorname{lgG} / \lg A$ antibody responses during Zika virus natural infection in two patients. J Med Virol. 2019 May;91(5):872-6. doi: 10.1002/jmv.25366.

36. Shan C, Xie X, Ren P, Loeffelholz MJ, Yang Y, Furuya A, et al. A rapid Zika diagnostic assay to measure neutralizing antibodies in patients. EBioMedicine. 2017 Mar;17:157-162. doi: 10.1016/j.ebiom.2017.03.006.
37. Tran A, Theel ES. The role of serologic testing for Zika virus infection. Rev Med Microbiol. 2018 Jan;29(1):1-7. doi: 10.1097/MRM.0000000000000122.

38. Gregory C), Oduyebo T, Brault AC, Brooks JT, Chung KW, Hills S, et al. Modes of transmission of Zika virus. J Infect Dis. 2017 Dec 16;216(10 Suppl):S875-83. doi: 10.1093/infdis/jix396.

39. Chang HH, Huber RG, Bond PJ, Grad YH, Camerini D, Maurer-Stroh S, et al. Systematic analysis of protein identity between Zika virus and other arthropod-borne viruses. Bull World Health Organ. 2017 Jul 1;95(7):51725. doi: 10.2471/BLT.16.182105.

40. Maciejewski S, Pierson TC. Cross-reactive flavivirus antibody: friend and foe? Cell Host Microbe. 2018 Nov 14;24(5):622-4. doi: 10.1016/j. chom.2018.10.016

41. Malafa S, Medits I, Aberle JH, Aberle SW, Haslwanter D, Tsouchnikas $\mathrm{G}$, et al. Impact of flavivirus vaccine-induced immunity on primary Zika virus antibody response in humans. PLoS Negl Trop Dis . 2020 Feb 4;14(2):e0008034. doi: 10.1371/journal.pntd.0008034.

42. Dejnirattisai W, Supasa P, Wongwiwat W, Rouvinski A, Barba-Spaeth G Duangchinda $T$, et al. Dengue virus sero-cross-reactivity drives antibodydependent enhancement of infection with zika virus. Nat immunol. 2016 Sep;17(9):1102-8. doi: 10.1038/ni.3515.

43. Priyamvada L, Hudson W, Ahmed R, Wrammert J. Humoral crossreactivity between Zika and dengue viruses: implications for protection and pathology. Emerg Microbes Infect. 2017 May 10;6(5):e33. doi: 10.1038/ emi.2017.42.

44. Watanabe S, Tan NW, Chan KW, Vasudevan SG. Dengue virus and Zika virus serological cross-reactivity and their impact on pathogenesis in mice. J Infect Dis. 2019 Jan 7;219(2):223-33. doi: 10.1093/infdis/jiy482.

45. Zaidi MB, Cedillo-Barron L, Almeida ME, Garcia-Cordero J, Campos FD, Namorado-Tonix K, et al. Serological tests reveal significant crossreactive human antibody responses to Zika and Dengue viruses in the Mexican population. Acta Trop. 2020 Jan;201:105201. doi: 10.1016/j. actatropica.2019.105201

46. Montecillo-Aguado MR, Montes-Gómez AE, García-Cordero J, CorzoGómez J, Vivanco-Cid H, Mellado-Sánchez G, et al. Cross-reaction, enhancement, and neutralization activity of dengue virus antibodies against zika virus: a study in the mexican population. J Immunol Res. $2019 \mathrm{Sep}$ 2;2019:7239347. doi: 10.1155/2019/7239347.

47. Caliendo AM, Gilbert DN, Ginocchio CC, Hanson KE, May L, Quinn TC, et al. Better tests, better care: improved diagnostics for infectious diseases. Clin Infect Dis. 2013 Dec;57(3 Suppl):S139-70. doi: 10.1093/ cid/cit578.

48. Rodriguez-Morales AJ, Galindo-Marquez ML, García-Loaiza CJ, SabogalRoman JA, Marin-Loaiza S, Ayala AF, et al. Mapping Zika virus infection using geographical information systems in Tolima, Colombia, 2015-2016. F1000Res. 2016 Apr 5;5:568. doi: 10.12688/f1000research.8436.1.

49. Center for Disease Control and Prevention [Internet]. Testing for Zika Virus [cited 2019 nov 13]. Available from: https://www.cdc.gov/zika/hcproviders/testing-for-zika-virus.html.

50. Corman VM, Rasche A, Baronti C, Aldabbagh S, Cadar D, Reusken CB, et al. Assay optimization for molecular detection of Zika virus. Bull World Health Organ. 2016 Dec 1; 94(12):880-92. doi: 10.2471/BLT.16.175950.

51. Shi W, Zhang Z, Ling C, Carr MJ, Tong Y, Gao GF. Increasing genetic diversity of Zika virus in the Latin American outbreak. Emerg Microbes Infect. 2016 Jul 6;5(7):e68. doi: 10.1038/emi.2016.68.

52. Roehrig JT, Hombach J, Barrett AD. Guidelines for plaque-reduction neutralization testing of human antibodies to dengue viruses. Viral Immunol. 2008 Jun;21(2):123-32. doi: 10.1089/vim.2008.0007.

53. Huzly D, Hanselmann I, Schmidt-chanasit J, Panning M. High specificity of a novel Zika virus ELISA in european patients after exposure to different flaviviruses. Euro Surveill. 2016 Apr 21;21(16). doi: 10.2807/1560-7917. ES.2016.21.16.30203.

54. L'Huillier AG, Hamid-Allie A, Kristjanson E, Papageorgiou L, Hung S Wong CF, et al. Evaluation of euroimmun anti-Zika virus IgM and IgG enzyme-linked immunosorbent assays for Zika virus serologic testing. J Clin Microbiol. 2017 Aug;55(8):2462-71. doi: 10.1128/JCM.00442-17. 
55. Kadkhoda K, Gretchen A, Racano A. Evaluation of a commercially available Zika virus IgM ELISA: specificity in focus. J Diag Microbio. 2017 Jul;88(3):233-5. doi: 10.1016/j.diagmicrobio.2017.04.002.

56. Steinhagen $K$, Probst $C$, Radzimski $C$, Schmidt-Chanasit J, Emmerich $P$, van Esbroeck M, et al. Serodiagnosis of Zika virus (ZIKV) infections by a novel NS1-based ELISA devoid of cross-reactivity with dengue virus antibodies: a multicohort study of assay performance, 2015 to 2016. Euro Surveill. 2016 Dec 15;21(50):30426. doi: 10.2807/1560-7917.ES.2016.21.50.30426.

57. InBios [Internet]. ZIKV Detect ${ }^{\top \mathrm{M}}$ IgM Carture ELISA Kit [cited 2019 Nov 8]. Available from: https://inbios.com/zikv-detecttm-igm-capture-elisa-kit-usa/.

58. Granger D, Hilgart H, Misner L, Christensen J, Bistodeau S, Palm J, et al. Serologic testing for Zika virus: comparison of three Zika virus IgMscreening enzyme-linked immunosorbent assays and initial laboratory experiences. J Clin Microbiol. 2017 Jul;55(7):2127-36. doi: 10.1128/ JCM.00580-17.

59. Safronetz D, Sloan A, Stein DR, Mendoza E, Barairo N, Ranadheera C, et al. Evaluation of 5 commercially available Zika virus immunoassays. Emerg Infect Dis. 2017 Sep;23(9):1577-80. doi: 10.3201/eid2309.162043.

60. Food and Drug Administration (US) [Internet]. Emergency use authorization [cited 2019 dec 18]. Available from: https://www.fda.gov/ medical-devices/emergency-situations-medical-devices/emergency-useauthorizations.

61. National Health Surveillance Agency (BR) [Internet]. [Health product consultation] [cited 2020 Jan 12]. Available from: https://consultas.anvisa. gov.br/\#/saude/. Portuguese.

62. Strottmann DM, Zanluca C, Mosimann AL, Koishi AC, Auwerter NC, Faoro $\mathrm{H}$, et al. Genetic and biological characterisation of Zika virus isolates from different Brazilian regions. Mem Inst Oswaldo Cruz. 2019;114:e190150. doi: 10.1590/0074-02760190150.

63. Zola H, Mohandas AP, Krumbiegel D. Monoclonal antibodies: diagnostic uses. In: eLS. Hoboken: John Wiley \& Sons; 2013. doi: 10.1002/9780470015902.a0002177.pub3.

64. Siddiqui MZ. Monoclonal antibodies as diagnostics: an appraisal. Indian J Pharm Sci. 2010 Jan;72(1):12-7. doi: 10.4103/0250-474X.62229.

65. Nagarajan T, Marissen WE, Rupprecht CE. Monoclonal antibodies for the prevention of rabies: theory and clinical practice. Antib Technol J. 2014:4:1-12. doi: 10.2147/ANTI.S33533.

66. Li FY, Lee B, Zhou JP, Tressel T, Yang X. Current therapeutic antibody production and process optimization. BioProcess J. 2006 Dec;5(4):16-25. doi: 10.12665/J54.LiZhou.

67. Dai L, Song J, Lu X, Deng YQ, Musyoki AM, Cheng H, et al. Structures of the Zika virus envelope protein and its complex with a flavivirus broadly protective antibody. Cell Host Microbe. 2016 May 11;19(5):696-704. doi: 10.1016/j.chom.2016.04.013.

68. Stettler K, Beltramello M, Espinosa DA, Graham V, Cassotta A, Bianchi $\mathrm{S}$, et al. Specificity, cross-reactivity, and function of antibodies elicited by Zika virus infection. Science. 2016 Aug 19;353(6301):823-6. doi: 10.1126/ science.aaf8505.

69. Zhao H, Fernandez E, Dowd KA, Speer SD, Platt DJ, Gorman MJ, et al. Structural basis of Zika virus-specific antibody protection. Cell. 2016 Aug 11;166(4):1016-27. doi: 10.1016/j.cell.2016.07.020.

70. Wang Q, Yang H, Liu X, Dai L, Ma T, Qi J, et al. Molecular determinants of human neutralizing antibodies isolated from a patient infected with Zika virus. Sci Transl Med. 2016 Dec 14;8(369):369ra179. doi: 10.1126/ scitransImed.aai8336.

71. Sapparapu G, Fernandez E, Kose N, Cao B, Fox JM, Bombardi RG, et al. Neutralizing human antibodies prevent Zika virus replication and fetal disease in mice. Nature. 2016 Dec 15;540:443-7. doi: 10.1038/nature20564.

72. Acharya D, Bastola P, Le L, Paul AM, Fernandez E, Diamond MS, et al. An ultrasensitive electrogenerated chemiluminescence-based immunoassay for specific detection of Zika virus. Sci Rep. 2016 Aug 24;6:32227. doi: 10.1038/srep32227.

73. Robbiani DF, Bozzacco L, Keeffe JR, Khouri R, Olsen PC, Gazumyan A, et al. Recurrent potent human neutralizing antibodies to Zika virus in Brazil and Mexico. Cell. 2017 May 4;169(4):597-609.e11. doi:10.1016/j. cell.2017.04.024.
74. Balmaseda A, Stettler K, Medialdea-Carrera R, Collado D, Jin X, Zambrana $\mathrm{JV}$, et al. Antibody-based assay discriminates Zika virus infection from other flaviviruses. Proc Natl Acad Sci U S A. 2017 Aug 1;114(31):8384-9. doi: 10.1073/pnas.1704984114.

75. Wu Y, Li S, Du L, Wang C, Zou P, Hong B, et al. Neutralization of Zika virus by germline-like human monoclonal antibodies targeting cryptic epitopes on envelope domain III. Emerg Microbes Infect. 2017 Oct 11;6(1):1-11. doi: 10.1038/emi.2017.79.

76. Zhang L, Du X, Chen C, Chen Z, Zhang L, Han Q, et al. Development and characterization of double-antibody sandwich ELISA for detection of zika virus infection. Viruses. 2018 Nov 15;10(11):634. doi: 10.3390/v10110634.

77. Kim YH, Lee J, Kim YE, Chong CK, Pinchemel Y, Reisdörfer F, et al. Development of a rapid diagnostic test kit to detect IgG/lgM antibody against zika virus using monoclonal antibodies to the envelope and nonstructural protein 1 of the virus. Korean J Parasitol. 2018 Feb 28;56(1):6170. doi: 10.3347/kjp.2018.56.1.61.

78. Li C, Gao F, Yu L, Wang R, Jiang Y, Shi X, et al. A single injection of human neutralizing antibody protects against $Z i k a$ virus infection and microcephaly in developing mouse embryos. Cell Rep. 2018 May 1;23(5):1424-34. doi: 10.1016/j.celrep.2018.04.005.

79. Pawley DC, Ricciardi MJ, Dikici E, Deo SK, Daunert S. highly sensitive and selective direct detection of Zika virus particles in human bodily fluids for accurate early diagnosis of infection. ACS Omega. 2019 Apr 30;4(4):6808-18. doi: 10.1021/acsomega.9b00374.

80. Long F, Doyle M, Fernandez E, Miller AS, Klose T, Sevvana M, et al. Structural basis of a potent human monoclonal antibody against Zika virus targeting a quaternary epitope. Proc Natl Acad Sci U S A. 2019 Jan 29;116(5):1591-96. doi:10.1073/pnas.1815432116.

81. Bosch I, Puig H, Hiley M, Carré-Camps M, Perdomo-Celis F, Narváez $C F$, et al. Rapid antigen tests for dengue virus serotypes and zika virus in patient serum. Sci Transl Med. 2017 Sep 27;9(409): eaan1589. doi: 10.1126/scitranslmed.aan1589.

82. Köhler G, Milstein C. Continuous cultures of fused cells secreting antibody of predefined specificity. Nature. 1975 Aug 1;256:495-7. doi: 10.1038/256495a0.

83. Lanzavecchia A, Corti D, Sallusto F. Human monoclonal antibodies by immortalization of memory B cells. Curr Opin Biotechnol. 2007 Dec;18(6):523-8. doi: 10.1016/j.copbio.2007.10.011.

84. Dantas-Barbosa C, Brigido MM, Maranhao AQ. Antibody phage display libraries: contributions to oncology. Int J Mol Sci. 2012 May 4;13(5):542040. doi: $10.3390 /$ ijms 13055420 .

85. Ravichandran S, Hahn M, Belaunzarán-Zamudio PF, Ramos-Castañeda J, Nájera-Cancino G, Caballero-Sosa S, et al. Differential human antibody repertoires following Zika infection and the implications for serodiagnostics and disease outcome. Nat Commun. 2019 Apr 26;10:1943. doi: 10.1038/ s41467-019-09914-3.

86. Fernandes CF, Pereira SS, Luiz MB, Zuliani JP, Furtado GP, Stabeli RG. Camelid single-domain antibodies as an alternative to overcome challenges related to the prevention, detection, and control of neglected tropical diseases. Front Immunol. 2017 Jun 9;8:653. doi: 10.3389/fimmu.2017.00653.

87. Leow $\mathrm{CH}$, Cheng Q, Fischer K, McCarthy J. The development of single domain antibodies for diagnostic and therapeutic applications. In: Böldicke T, editor. Antibody engineering. London: IntechOpen; 2018. p. 175-204. doi: 10.5772/intechopen.73324.

88. Wang L, Filer JE, Lorenz MM, Henry CS, Dandy DS, Geiss BJ, et al. An ultra-sensitive capacitive microwire sensor for pathogen-specific serum antibody responses. Biosens Bioelectron. 2019 Apr 15;131:46-52. doi: 10.1016/j.bios.2019.01.040.

89. Mishra N, Caciula A, Price A, Thakkar R, Ng J, Chauhan LV, et al. Diagnosis of Zika virus infection by peptide array and enzyme-linked immunosorbent assay. mBio. 2018 Mar 6;9(2):e00095-18. doi: 10.1128/mBio.00095-18.

90. Kareinen L, Hepojoki S, Huhtamo E, Korhonen EM, Schmidt-Chanasit J, Hedman K, et al. Immunoassay for serodiagnosis of Zika virus infection based on time-resolved Förster resonance energy transfer. PLoS One. 2019 Jul 23;14(7):e0219474. doi: 10.1371/journal.pone.0219474. 
91. Zhang B, Pinsky BA, Ananta JS, Zhao S, Arulkumar S, Wan H, et al. Diagnosis of Zika virus infection on a nanotechnology platform. Nat Med. 2017 Mar 6;23(5):548-50. doi:10.1038/nm.4302.

92. Collins MH. Serologic tools and strategies to support intervention trials to combat Zika virus infection and disease. Trop Med Infect Dis. 2019 Apr 19;4(2):68. doi: 10.3390/tropicalmed4020068.
93. Caliendo AM, Gilbert DN, Ginocchio CC, Hanson KE, May L, Quinn TC, et al. Better tests, better care: improved diagnostics for infectious diseases. Clin Infect Dis. 2013 Dec 1;57(3 Suppl):S139-70. doi: 10.1093/ cid/cit578.

94. World Health Organization. Zika virus outbreak global response: interim reports. Geneva: World Health Organization; May 2016. 